\title{
RE-EVALUATION OF ANIMAL PROTECTION BY THE FINNISH ANIMAL RIGHTS LAWYERS SOCIETY
}

\author{
BIRGITTA WAHLBERG ${ }^{1}$ \\ ${ }^{1}$ Åbo Akademi University, Department of Law, Gezeliusgatan 2, 20500 Åbo, Finland. ORCID: 0000- \\ 0002-2895-5621, E-mail: birgitta.wahlberg@abo.fi
}

\begin{abstract}
The recognition of animals as sentient beings in the Treaty on the Functioning of the European Union (TFEU) gave rise to expectations as to real concern and care for animal welfare and a balance of human-animal interests. However, both the EU-legislation and the Finnish animal protection legislation is based on an animal welfare paradigm, meaning that animals have a weak legal status compared to humans that makes it impossible to de facto balance human and animal needs and interests in an effective manner from an animal point of view. The weak legal status of animals in the hierarchy of norms in the Finnish legal system contributes to the continuation of the oppression and exploitation of animals. The Finnish Animal Rights Lawyers Society have therefore made a proposal to strengthen animals' legal status by including animals in the Finnish Constitution (FC) by safeguarding animals' certain fundamental rights, thereby providing tools for balancing of human-animals interests. This article focuses on the re-evaluation of animal protection from an animal and constitutional point of view.

KEYWORDS: human-animal interests, animal law, animal's fundamental rights, re-evaluation of animal protection
\end{abstract}

\section{THE FINNISH LEGAL SYSTEM AND SOURCES OF LAW IN RELATION TO ANI- MALS}

The main questions in this article are how animals' ${ }^{11}$ Legal status and protection from

\footnotetext{
1 "Animals" refers to all other species than humans, homo sapiens, in other words to nonhumans. The article
} 
harmful human impact can be strengthened in law and how we can move towards a more respectful and balanced coexistence between humans and nonhumans. The recognition of animals as sentient beings in the Treaty on the Functioning of the European Union (TFEU) gave rise to expectations as to genuine concern and care for animal welfare and a balance of human-animal interests. However, both EU legislation and Finnish animal protection legislation are based on an animal welfare paradigm that it is acceptable to use animals for human purposes as long as we treat them well and do not impose unnecessary suffering on them (more precisely about the welfare paradigm in Francione \& Garner 2010). This in itself, however, limits what is possible to achieve in terms of the law for the protection of animals, as I will explore further in this article.

In accordance with the hierarchy of norms and Finland's membership of the European Union (EU) since 1995, Finland's national legislation and interpretation of the laws concerning animal protection have been bound by EU treaties and the animal protection legislation of the EU. The content of Article 13 in the TFEU demands that since animals are sentient beings, both the Union and the Member States shall in formulating and implementing the Union's agriculture, fisheries, transport, internal market, research, technological development and space policies, take fully into account the welfare requirements of animals, while respecting the legislative or administrative provisions and customs of the Member States (MS) relating in particular to religious rites, cultural traditions and regional heritage ${ }^{2}$. Considering that animals are also classified as "agricultural products" within the TFEU ${ }^{3}$ And that animal welfare is not one of the objectives of the Union set out in the Treaty on European Union (TEU) Articles $2-3^{4}$, the notion of "sentient beings" and the requirement to "pay full regard

includes mainly animals that are used in food production.

${ }^{2}$ Consolidated version of the Treaty on the Functioning of the European Union, OJ C 202, 7.6.2016, p. 1-388 (EN).

${ }^{3}$ TFEU Article 38

${ }^{4}$ Article 2: "The Union is founded on the values of respect for human dignity, freedom, democracy, equality, the rule of law and respect for human rights, including the rights of persons belonging to minorities. These values are common to the Member States in a society in which pluralism, non-discrimination, tolerance, justice, solidarity and equality between women and men prevail." Article 3: "1. The Union's aim is to promote peace, its values and the well-being of its peoples. 2. The Union shall offer its citizens an area of freedom, security and justice without internal frontiers, in which the free movement of persons is ensured in conjunction with appropriate measures with respect to external border controls, asylum, immigration and the prevention and combating of crime. 3 . The Union shall establish an internal market. It shall work for the sustainable development of Europe based on balanced economic growth and price stability, a highly competitive social market economy, aiming at full employment and social progress, and a high level of protection and improvement of the quality of the environment. It shall promote scientific and technological advance. It shall combat social exclusion and discrimination, and shall promote social justice and protection, equality between women and men, solidarity between generations and protection of the rights of the child. It shall promote economic, social and territorial cohesion, and solidarity among Member States. It shall respect its rich cultural and linguistic diversity, and shall ensure that Europe's cultural heritage is safeguarded and enhanced. 4. The Union shall establish an economic and monetary union whose currency is the euro. 5 . In its relations with the wider world, the Union shall uphold and promote its values and interests and contribute 
to" in relation to the MS legislative and administrative provisions and customs, the content seems primarily to be a justification for the conventional use of animals for human purposes (See in further detail the complex set of questions the TFEU gives raise to in Sowery 2018:55).

According to the Finnish Constitution (FC 731/1999) Chapter 8, Sections 94 and 96, the Parliament's approval is required for treaties and other international obligations that contains provisions of a legislative nature. The Parliament considers the proposals for acts, agreements and other measures that are to be decided in the EU. An Act of Parliament is adopted once Parliament has approved a government bill for the act and the President of the Republic signs the law to come into force ${ }^{5}$. The authorisation to issue Decrees has to be given in the FC, or in another Act, to the President of the Republic, the Government or a Ministry. ${ }^{6}$ The principles governing the rights and obligations of private individuals and other matters that under the FC are of a legislative nature shall, however, be governed by an Act.

There is no Constitutional Court in Finland, but the Parliament's Constitutional Law Committee shall issue statements on the constitutionality of legislative proposals as well as on their relation to international human rights treaties and other international commitments ${ }^{7}$.

It is stated in the Constitution that Decrees or other statutes of a lower level than an Act shall not be inconsistent with the FC or another Act. In such a case, the courts or any other public authority shall not apply them ${ }^{8}$. In matters where the application of an Act would be in evident conflict with the FC, the courts have to give primacy to the provision in the $\mathrm{FC}^{9}$. Additionally, according to the Code of Judicial Procedure (4/1704), Section 11, "A judge shall carefully examine the true purpose and grounds for the law and render judgment accordingly, and not as he or she pleases, against the law. In the absence of statutory law, the custom of the land, if not unreasonable, shall also be his or her guide in rendering judgment”.

The sources of law are classified into groups according to their degree of binding force and position in the hierarchy of legal sources. The status of the sources is divided into authoritative and substantive sources of law (justification). The hierarchy of national statutes is categorised from strongly binding sources of law to permitted sources of law as follows:

to the protection of its citizens. It shall contribute to peace, security, the sustainable development of the Earth, solidarity and mutual respect among peoples, free and fair trade, eradication of poverty and the protection of human rights, in particular the rights of the child, as well as to the strict observance and the development of international law, including respect for the principles of the United Nations Charter. 6. The Union shall pursue its objectives by appropriate means commensurate with the competences which are conferred upon it in the Treaties." Consolidated version of the Treaty on European Union. OJ C 202, 7.6.2016: 13-388.

${ }^{5}$ FC Chapter 6, Section 77.

${ }^{6} \mathrm{FC}$ Chapter 6, Section 80. If there is not an authorization, the Decree has so be given by the Government.

${ }^{7}$ FC Chapter 6, Section 74.

${ }^{8}$ FC Chapter 10, Section 107.

${ }^{9}$ FC Chapter 10, Section 106. Note that this obligation concerns only courts, not other authorities. 
Strongly binding/Authoritative sources: European Union (EU) law and the Finnish Constitution, Act (Act of Parliament), Decree, Decision of the Council of Ministers, Decision of a Ministry, other authoritative instructions (based on an Act), i.e. written law. Established custom is a strong binding source of law as substantive justification (substantive source of law).

Weakly binding/Substantive sources: Court decisions, Travaux Préparatoires (Government Bills).

Permitted: Jurisprudence (official justification), general principles of law (substantive justification), factual arguments (substantive justification), and morality (substantive justification) (Pöyhönen 2002:24-30).

The essence of the hierarchy of norms is that a lower-level statute can only be given based on a provision on a higher-level statute. An interpreter can decline from following the prevailing law when a provision in a national statute of the lower level is in conflict with a higher-lever provision, or when a provision in a national statute is in conflict with a supranational provision ${ }^{10}$. In practice, it is rare for national or supranational provisions to be in direct conflict. It is more common than the national interpreter must choose the alternative that is most in harmony with the provisions in the supranational legislation (Pöyhönen 2002:27).

Depending on the legal context in question, animals in the legal system are considered as:

(a) legal objects that are protected by laying some welfare requirements on humans, i.e. animals do not have fundamental, subjective rights as humans (natural persons) or rights as legal persons, but have to be taken care of and be protected by humans to a certain degree ${ }^{11}$ (the welfarist approach);

(b) property as in the context of property law, meaning, for example, that a property owner has a right to sell, give away or euthanise an animal (the property) $;^{12}$

(c) things as referred to in the Finnish Trade Code as things that can be borrowed or rented. "who borrows something from the other, without breath or living, give it back as good as it was. [...]"13. Concern such as renting "horses, wagons and

\footnotetext{
${ }^{10} \mathrm{~A}$ third option is that a provision has fallen into desuetude. However, its significance is nearly non-existent in practice.

${ }^{11}$ Note that Kurki points out that animals already are holders of certain rights (as 'animal persons') because of humans decire to protect them from suffering by law (the legal safeguards that are designated as rights), but these are not fundamental rights. The outcome depends on the incidents the rights are endowed with (Kurki 2017).

${ }^{12}$ In divorce situations, animals are considered as property and dealt with accordingly based on the Marriage Act 234/1929, the Sale of Goods Act 355/1987, the Act on Certain Joint Ownership Relationships 180/1958, the Act on the Dissolution of the Household of Cohibiting 26/2011 and the Animal Protection Act 247/1996.

${ }^{13}$ Finnish Trade Code 3/1734, Chapter 11, Section 1.
} 
boats" are assimilated in the code ${ }^{14}$.

Furthermore, "wild animals" 15 are placed in a different legal position from other animals, one can argue, by the recognition of the intrinsic value of nature, which wildlife is part of, as recognised in the Government Bill to the Finnish Constitution (GBFC), Section 20. However, this recognition is not written into Section 20 and is thereby not authoritative and influential binding concerning the sources of law. Nevertheless, species can be protected, and the public can be addressed with requirements under the Nature Conservation Act (1096/1996), and administrative coercive measures can be taken against individuals who violate the Animal Protection Act (APA 247/1996), which applies to all animals. In that respect, wildlife has, at least theoretically, a stronger legal status in Finnish law than other animals. However, environmental regulations do not generally focus on animals as sentient beings (or animal individuals), but on the species.

Since the current Constitution entered into force in 2000, constitutional anchoring has been strengthened in ordinary law and in the interpretation of the law in Finland. Thus, on what level in the hierarchy of norms, the provisions are legislated upon is substantial for the outcome. This is particularly important to bear in mind with regard to the possibilities to balance human-nonhuman interests according to the law.

Fundamental human rights are legislated in the EU at the primary law level ${ }^{16}$ and in Finland in the Finnish Constitution ${ }^{17}$, the protection of animals is legislated in the EU at both the primary ${ }^{18}$ and secondary ${ }^{19}$ law levels, while in Finland only at an ordinary

\footnotetext{
${ }^{14}$ Finnish Trade Code Chapter 13, Section 13(4). In the Construction Code is also laid down the provisions on how to keep animals and how to keep them from doing damage. Finnish Construction Code 2/1734 Chapter 9, 11, 12, 21 and 22. Note that these are ancient provisions, but still in force.

${ }^{15}$ Meaning animals living in nature without interference or help from humans.

${ }^{16}$ Charter of Fundamental Rights of the European Union, OJ C 202, 7.6.2016, p. 391-407.

${ }^{17}$ FC Chapter 2.

${ }^{18}$ TFEU Article 13. However, note the content of the article which from an animal perspective is quite meaningless.
}

${ }^{19}$ Regulations: Council Regulation (EC) No 1099/2009 of 24 September 2009 on the protection of animals at the time of killing, OJ L 303, 18.11.2009, p. 1-30; Regulation (EC) No 1523/2007 of the European Parliament and of the Council of 11 December 2007 banning the placing on the market and the import to, or export from, the Community of cat and dog fur, and products containing such fur, OJ L $343,27.12 .2007$, p. 1-4 (the ordinance protects cats and dogs indirectly); Council Regulation (EC) No 1/2005 of 22 December 2004 on the protection of animals during transport and related operations and amending Directives 64/432/EEC and 93/119/EC and Regulation (EC) No 1255/97, OJ L 3, 5.1.2005, p. 1-44. Directives: Directive 2010/63/EU of the European Parliament and of the Council of 22 September 2010 on the protection of animals used for scientific purposes, OJ L 276, 20.10.2010, p. 33-79; Council Directive 2007/43/EC of 28 June 2007 laying down minimum rules for the protection of chickens kept for meat production, OJ L 182, 12.7.2007, p. 19-28; Council Directive 2008/119/EC of 18 December 2008 laying down minimum standards for the protection of calves, OJ L 10, 15.1.2009, p. 7-13; Council Directive 2008/120/EC of 18 December 2008 laying down minimum standards for the protection of pigs, OJ L 47, 18.2.2009, p. 5-13; Council Directive 1999/74/EC of 19 July 1999 laying down minimum standards for the protection of laying hens, OJ L 203, 3.8.1999, p. 53-57; Council Directive 1999/22/EC of 29 March 1999 relating to the keeping of wild animals in zoos, OJ L 94, 9.4.1999, p. 24-26; Council Directive 98/58/EC of 20 July 1998 concerning the protection of animals kept for farming purposes, OJ 
law level (i.e. an Act of Parliament) ${ }^{20}$. In the light of the hierarchy of norms and the content of Article 13 in the TFEU and TEU Article 3-4 as points of reference for animal protection legislation in Finland (and in the EU), it is actually impossible in legal terms to de facto balance human and animal needs and interests in an effective manner by significantly taking into account also the animal perspective, i.e. animals' needs and interests (In detail Sowery 2018). This combined with the lack of statutes concerning animals in the Finnish Constitution together with the traditional understanding of animals mainly as objects, products, protected by an anthropocentric view, ensures the superiority of humans in relation to other sentient beings in both legal and practical terms.

Thus, at the same time as more statutes than ever are in force with the aim to protect animals ${ }^{21}$, it is nevertheless legal that every year millions of animals are bred, raised, kept, killed and slaughtered by human unnecessarily for human survival additionally to the detriment of nature. Specifically farm animals are excessively exploited by humans; for instance, in Finland alone, 79475404 animals, i.e. sentient beings (cattle, pigs, poultry, sheep, goats and horses) were slaughtered in $2018^{22}$, also mean-

L 221, 8.8.1998, p. 23-27.

${ }^{20}$ Three (3) acts are in force protecting animals in a direct way in Finland: Animal Protection Act 247/1996, Animal Transportation Act 1429/2006 and Animal Protection During Experimentation Act $497 / 2013$ (the translations are not official). Furthermore there is seventeen (17) decrees in force for the protection of animals (given on the basis of an authorisation given in the acts mentioned): Government Decree on the Protection of Sheep 587/2010, Government Decree on the Protection of Goats 589/2010, Government Decree on the Protection of Farmed Deer 590/2010, Government Decree on the Protection of Pigs 629/2012, Government Decree on the Protection of Bovine Animals 592/2010, Government Decree on the Protection of Ostriches 676/2010, Government Decree on the Protection of Chickens 673/2010, Government Decree on the Protection of Dogs, Cats and Other Small Pet Animals 674/2010, Government Decree on the Protection of Horses 588/2010, Government Decree on the Protection of Farmed Bison 591/2010, Government Decree on the Protection of Fur Animals 1084/2011, Government Decree on the Protection of Ducks and Geese 675/2010, Government Decree on the Protection of Turkeys 677/2010, Government Decree on the conservation of farmed fish 812/2010, Government Decree on the Protection of Chickens 375/2011, Ministry Decree on Prohibition of Use of Dogs in Animal Competitions or Display that have Undergone an Alteration to the Appearance 1070/2000, Ministry decree on Animal Welfare Requirements for the Holding of Animals in a Zoo and in Permanent Animal Exhibition 2/EEO/2003. There is also three (3) binding decisions by the Ministry of Agriculture and Forestry of Finland: Animal protection requirements for the slaughter of animals 23 / EEO / 1997, Animal protection requirements for the killing of farm animals of mammalian and bird species 18/EEO/96,

Animals Protection in a Circus and Other Comparative Exhibition 22 / EEO / 96. Note that the translations of the names are not official All the animal protection legislation can be found on the Ministry of Agriculture and Forestry of Finland's webpage: https://mmm.fi/lainsaadanto/elaimet-elintarvikkeet-ja-terveys/lainsaadanto/f-rekisteri (only in Finnish) and by ordinance number at www.finlex.fi (the acts in English).

21 "Nature" in its extensive meaning including the context of "environment" and "climate" (In detail IUCN Annual Report 2018, Rojas-Downing et.al. 2017:16: 145-163, Isomäki 2016, Gerten et.al. 2015:348(6240), Bailey et.al. 2014, Scarborough et.al. 2014:125:179-192, Koneswaran et.al. 2008:116(5): 578-582).

${ }^{22}$ Natural Resources Institute Finland's (Luke) webpage: http://statdb.luke.fi/PXWeb/pxweb/en/LUKE/ LUKE 02\%20Maatalous 04\%20Tuotanto 06\%20Lihantuotanto/02 Lihantuotanto teurastamoissa_v.px/ table/tableViewLayout1/?rxid=a7659b81-5c13-4105-b63e-037f817a31e1. Retrieved February 2019. Fish are 
ing an industry which is impacting our universal nature negatively. Furthermore, the use, breeding and trading of "companion animals" (also called "pet animals") have increased every year ${ }^{23}$, as well as - I would dare to claim - the suffering caused to these animals by human impact, for instance, by breeding and trading. This is not to overlook the harm that hunting cause to animals' possibility to live and to the eco-balance of nature. ${ }^{24}$

If life itself is considered as fundamentally valuable to sentient beings, and oppression and exploitation as forms of violence against them, it is clear merely from these numbers that the aim of animal protection law is not fulfilled from an animal perspective. By this, I am not claiming that all co-existence between humans and animals is characterised by oppression and exploitation, but I claim that the oppression and exploitation of animals we are witnessing today is an inevitable outcome of current animal protection legislation. This is due to the weak constitutional basis of the protection of animals combined with the legislation based on the animal welfare paradigm, i.e. an anthropocentric animal protection legislation ${ }^{25}$

\section{THE OBJECTIVE OF THE FINNISH ANIMAL PROTECTION LAW}

When reviewing the content of the animal protection legislation, the lack of legal consistency and justification for the use of animals for human purposes is apparent. The grade of protection that is targeted at an animal depends on: 1) the human interest and context in which the animal or species in question is used, i.e. a pig on a farm can legally be caused pain and have a much more restricted life compared to a pig living as a "companion". It is, for example, legal on a farm to castrate a piglet younger than eight days without any painkilling medicine or anaesthesia ${ }^{26} ; 2$ ) the effectiveness for humans of the action in question, e.g. to keep sows in farrowing crates where they cannot move other than to lie down or stand up and take one step backwards and

not counted as individuals but as $\mathrm{kg} /$ person. In 2017 the consumption of fish was 13,9 kg/person. Luke: http://statdb.luke.fi/PXWeb/pxweb/en/LUKE/LUKE $\quad 06 \% 20 \mathrm{Kala} \% 20$ ja\%20riista $\quad 06 \% 20$ Muut $\quad 02 \% 20$ Kalan\%20kulutus/2_Kalankulutus.px/table/tableViewLayout2/?rxid=9fbe13f2-4b82-4e42-bb9c-76c551b27c91. Retrieved February 2019.

${ }^{23}$ According to the Statistic Finland, $35 \%$ of the households had a pet animal in 2016 (latest statistic): http://tilastokeskus.fi/til/ktutk/2016/ktutk_2016_2016-11-03 tie_001_en.html?ad=notify. Retrieved February 2019.

It is reasonable to assume that the number of households keeping animals has increased during the past years. In the U.S., the companion animal industry is the seventh-largest retail industry (Hessler et al. 2017:xxxi).

${ }^{24}$ According to the latest hunting legislation raccoon dogs, minks, aphids, junkies and raccoons can be caught all year round from June 2019, even during the spring, which is usually forbidden due to ethical reasons. Government Decree on the Management of the Risks of Alien Species 704/2019.

${ }^{25}$ Also called animal welfare legislation in some countries. See the overview of the current laws on Global Animal Law Project's webpage: https://www.globalanimallaw.org/database/national/index.html. Retrieved February 2019.

${ }^{26}$ The Finnish Animal Protection Decree 396/1996, Section 23(5). Furthermore, the starting point for a pig on a farm is that it will be slaughtered contrary to the pig as a companion. 
forwards, which are generally illegal actions in keeping animals, but legal on farms to make "production" effective ${ }^{27}$; and 3) the jurisdiction in which the action takes place, e.g. a person who owns a mouse cannot legally cause the mouse pain with a needle, but the same person can go to work as a researcher and legally use a needle on a mouse in a laboratory ${ }^{28}$.

Apart from the Preamble (10) to the Directive 2010/63 on the protection of animals used for scientific purposes, where it is stated that "While it is desirable to replace the use of live animals in procedures by other methods not entailing the use of live animals, the use of live animals continues to be necessary to protect human and animal health and the environment", there is no criterion of necessity laid down in EU or Finnish animal protection legislation for the use of animals. In other words, the use and level of protection depending on the human context. One may question if the different contextual outcomes that cause animal suffering or significantly limit animals' living conditions or possibilities, i.e. the reality in which several animals live under human control, are supported by science-based knowledge concerning animals that the animal protection laws are supposed to be based on ${ }^{29}$. It is common knowledge

${ }^{27}$ The Government Decree on the Protection of Pigs 629/2012, Section 3. Note that there are some time limits for the action. However, sows live most of their lives in these crates. Farmers usually justify the use of crates by claiming that it is for the protection of the piglets. Nevertheless, the death of piglets by suffocation under the sow is avoidable by offering more space and possibility for the sow to build a proper nest OR by the best option from an animal perspective, with no 'production' of pigs.

${ }^{28}$ Animal Protection Act 247/1996, Article 12 (2): "An animal may not be injured or treated in a violent manner. [...]", and the Directive 2010/63/EU of the European Parliament and of the Council of 22 September 2010 on the protection of animals used for scientific purposes, OJ L 276, 20.10.2010, p. 33-79: Chapter 1, Article 1(5): "This Directive shall not apply to the following: [...] (f) practices not likely to cause pain, suffering, distress or lasting harm equivalent to, or higher than, that caused by the introduction of a needle in accordance with good veterinary practice."

${ }^{29}$ However, also the current aim to have a science-based animal protection legislation has an anthropocentric goal expressed, e.g. in the European Parliament resolution of 26 November 2015 on a new animal welfare strategy for 2016-2020 (2015/2957(RSP)) as follows: „A. whereas EU legislation in the field of animal welfare contributes to a level playing field within the Union and thereby to a well-functioning internal market; [...] C. whereas national rules on animal welfare must not be contrary to the principles of the EU single market; [...] E. whereas, owing to their complexity and differing interpretations, EU and national rules on animal welfare create legal uncertainty and can put producers in the certain Member States at a serious competitive disadvantage; [...] G. whereas animal welfare should be further improved on the basis of prevailing scientific findings and with due regard for the efficiency and competitiveness of agricultural livestock husbandry; whereas coherent animal welfare standards across the EU would benefit from a definition of good animal husbandry; [...] 3. Calls on the Commission to ensure an updated, comprehensive and clear legislative framework which fully implements the requirements of Article 13 of the TFEU; reiterates, however, that under no circumstances must animal welfare levels be lowered on account of administrative simplification; stresses that these objectives are not mutually exclusive; 4 . Stresses that Article 13 of the TFEU is of general application and horizontal, and as such is as important as the provisions on agriculture, the environment or consumer protection; [...] 13. Recalls that producers are overburdened with administrative requirements and that, in the continued search for administrative simplification, this European strategy should not further increase the existing burden; stresses the need to ensure stability and predictability of investments in the sector, while ensuring fair competition internationally; [...]" OJ C 366, 27.10.2017, p. 149-150. 
today that humans cause many animals severe suffering unnecessarily for our own survival or good quality of life.

The objective of the Finnish Animal Protection Act, Section 1, is to protect animals from distress, pain and suffering in the best possible way and to promote the welfare and proper treatment of animals. However, in Section 3 of the APA concerning the general principles of keeping animals, the prohibition to inflict suffering, distress or pain on animals is limited to undue suffering, pain and distress ${ }^{30}$. Concerning the objective to promote animal welfare, the same provision requires that animals' physiological and behavioural needs must be taken into account in the keeping of animals, in other words, both in the legislation based on the Act and in the application of the law. Yet, this does not mean that animals' needs, not to mention rights, have to be satisfied or that their interests have to be balanced with human interests. Nor is it necessary to justify the use of animals for human purposes in the law. It is taken as a given that humans can use animals and inflict severe suffering on them according to the law, even though it is not explicitly expressed this way in the provisions.

Since 2010, an overall reform of the legislation concerning animal protection has been in progress in Finland. In the Government Bill to the new Animal Welfare Act (GB $154 / 2018)^{31}$, the objective of the Act is phrased as follows: "to promote animal welfare and to protect animals in the best possible way from harm to their welfare. The aim is also to increase respect for animals and ethical treatment”. As a general principle and responsibility, it is required that "animals must be treated well and be respected. It is prohibited to inflict undue pain or to suffer on animals, or to jeopardise animal welfare" ${ }^{32}$.

Compared to the objective of the APA in force, the objective of the new act, as written in the GB, is rhetorical and does not appear to represent fundamental changes in the protection of animals or in society concerning the use of animals. Both the current and the suggested objectives illustrate an animal welfare paradigm that aims to make the use of animals for human purposes more "humane" and ensures a continuation of the anthropocentric regulation. Therefore, the proposed objective, in combination with animals' weaker status in relation to humans and humans' fundamental rights, is that there are no fundamental changes to be expected from the law reform. It should be borne in mind that the objective of the law is significant also for the provisions issued by Decrees because an interpreter may not overrule the purpose of the law in the interpretation of the applicable provisions in $\mathrm{cas}^{33}$.

\footnotetext{
30 "(1) Animals must be treated well, and no undue distress may be caused to them. Inflicting undue pain and distress on animals is prohibited. In addition, maintaining the health of animals must be promoted in keeping animals, and the physiological and behavioural needs of the animals must be taken into account.

(2) Further provisions as to what is to be considered as inflicting undue distress, pain and suffering on animals may be issued by Decree." APA, Section 3.

${ }^{31}$ Note that the Act is not yet in force.

${ }^{32}$ Note that the translations are unofficial.

${ }^{33}$ The European Court of Justice (ECJ) has determined that the interpretation of applied provisions in casu shall not lead to such an outcome that the objective is nullified. See, e.g. C-300/05, C-455/06, C-491/06, C-416/07. For
} 
It is entirely possible for humans to co-exist with other animals in a respectful manner. This meaning an existence in non-violence where different needs and interests are de facto balanced in conflict situations for the benefit of both humans and animals (and nature which we have in common). A respectful coexistence requires a possibility to de facto balance human and animal needs and interests by law. An establishment of effective legal tools for balancing of these interests requires in turn that animals' legal status is stronger in relation to humans. The instrumentalised and anthropocentric approach towards animals in law only determines the poor level of protection granted to animals in reality.

However, the ongoing reform in Finland does not include the establishment of animals' fundamental rights in the FC, which would significantly change the legal status of animals in relation to humans. Such a constitutional amendment would have a significant impact on the content of the entire animal protection legislation and on the interpretation and application of the written law made by the courts and other authorities. It would also force every human being to re-evaluate their relationship to animals and the use of animals for human purposes. In the following chapter, I will introduce the legal tools provided by the Finnish Animal Rights Lawyers Society for this purpose.

\section{SAFEGUARDING CONSTITUTIONAL RIGHTS TO ANIMALS}

Because there appears to be no indication that the basis of animals' legal status nor the content of the animal protection legislation would be significantly developed from an animal perspective by the animal protection/welfare law reform, a group of lawyers and legal scholars - the Finnish Animal Rights Lawyers Society, have written a proposal to include animals in the FC by safeguarding certain fundamental rights for animals. ${ }^{34}$ The proposal re-evaluates the current protection of animals with a focus on the legal status of animals and animals' fundamental rights.

The proposal for the fundamental rights of animals is divided into five sections: Section 1 concerns general terms of animal protection (four subsections); Section 2 deals with safeguarding fundamental animal rights (two subsections), whilst, Section 3 focuses on the fundamental rights of wild animals (two subsections); Section 4 examines the fundamental rights of animals dependent on human care (five subsections), and Section 5 is a prohibition on animal breeding. In this paper, only the main content of the rationale is presented. ${ }^{35}$ The chapter division in the paper follows the article division in the proposal.

\footnotetext{
general comments about the interpretations made by the ECJ in animal protection cases (see also Wahlberg 2011, available only in Swedish).

${ }^{34}$ The proposal is made by Wahlberg, Birgitta, Dr.Soc.Sc (public law), university teacher at Åbo Akademi University (President) \& Kurki, AJ Visa, J.D., researcher at the University of Helsinki (Vice-President) \& Pirilä, Susanna, LL.M. (Secretary) \& Koskela, Tarja, J.D., university lecturer at the University of Eastern Finland (Member of the Board) \& Jäntti, Albert, law student at the University of Helsinki and Kanninen, Roope, law student at the University of Lapland.

${ }^{35}$ See the whole proposal and its rationale (translation from the original Finnish version) on the Finnish Animal Rights Lawyers Society’s homepage: https://www.elaintenvuoro.fi/\#english. Retrieved April 2019.
} 


\subsection{General terms on animal protection}

According to Article 13 in the TFEU, in the proposal Section 1, subsection 1, animals are recognised as sentient beings. Sentient beings are individuals, and a sentient individual has intrinsic value. Sentience is defined as a capability for experiencing positive and negative emotions. However, it is currently not possible to make a precise distinction between sentient and insentient species, especially in assessing the sentience of invertebrate species. The delimitation of sentient and insentient species is continually changing, and thus, when determining individual sentience in practice, a Principle of Precaution has to be applied for the benefit of the animal. According to the precautionary principle, all animals are considered sentient unless there is evidence to the contrary.

Furthermore, respect for animal sentience entails that the self-understanding or cognitive capacities, or incapacities, of animals are irrelevant with regard to the protection of animals. Humans must protect a sentient being for its own sake as an individual. However, the capacities of an animal affect the intensity and variety of its experiences. This, in turn, is of relevance when assessing the optimal interests of the animal according to the best scientific understanding and knowledge. Thereby, the lack of scientific certainty cannot be an excuse for neglecting the fundamental animal rights.

Perhaps the essential requirement in the proposal is that, according to Section 1, subsection 2: the interests of animals and their individual needs must be taken into account in all public and private activities that have a significant impact on animals' living conditions or possibilities. ${ }^{36}$ An activity will substantially affect the living conditions or possibilities of an animal if it affects the fulfilment of the animal's fundamental rights granted under Sections 3-5 in the proposal. Among other issues, the special status of an animal means that there is an obligation to take into account its individual qualities in all decision-making. The fulfilment of species-specific needs alone does not suffice. According to subsection 1, the resolution of matters concerning an animal must be based on available scientific information on animal welfare and also, if possible, available information on the animal's individual needs and habits.

According to subsection 3, animals have legal standing before the authorities and in the courts. Legal representatives shall be authorised by an Act to speak on the animal's behalf. Such a representative shall be heard in legal proceedings that concern the animal's rights or interests, and he or she may appeal the decision on the animal's behalf. The animal's owner may represent the animal if the interests of the animal and the owner do not conflict. This kind of arrangement is not unusual in Finnish law. Under certain conditions, registered associations and foundations have the right to appeal against authority decisions under the Nature Conservation Act (1096/1996), the Environmental Protection Act (527/2014), the Water Act (587/2011) and the Waste Act (646/2011).

\footnotetext{
${ }^{36}$ This idea is based on the argumentation presented by Pietrzykowski in 2018 on why animals' interests should be taken into account in all decision-making. In the proposal, the word 'living conditions' refers to animals dependent on human care and the word 'living possibilities' to wild animals.
} 
Ensuring the fundamental rights, welfare and protection of animals is the responsibility of every one according to subsection 4. Similar to Article 20 of the FC (Chap. 2 ), which states that nature is the responsibility of everyone, this responsibility lies with public authorities as well as natural persons and legal persons. This means that everyone has a specific duty according to the FC to treat animals in accordance with the fundamental rights of animals and the animal welfare regulations. This duty applies to both animals dependent on human care as well as wild animals and does not depend on who the owner of the animal is, or whether the animal is owned by anyone. By providing that this responsibility belongs to everyone, it is also emphasised that the animal protection pursuant to Section 1 calls for extensive cooperation between the various authorities and other parties.

The aim is for a balanced assessment of the interests of humans and other animals. The responsibility for animals includes caring for the typical living environment and respecting all sentient individuals that live there with due regard for their fundamental rights. This responsibility includes both the promotion of animal welfare and the elimination and prevention of suffering. The contribution of an individual person to the protection of animals and the assurance of animal rights may take the form of actively pursuing or passively refraining from actions that infringe upon animal rights. Although animals' fundamental rights and the rights of human beings are not the same, they shall be equivalent as a starting point when weighed against each other.

\section{2. Safeguarding fundamental animal rights}

Section 2, subsection 1, stipulates explicitly that public authorities must safeguard fundamental rights for every animal within their jurisdiction. This corresponds to the obligation of public authorities to safeguard the fundamental human rights stipulated in Section 22 of the FC. Such safeguarding means a constitutional mandate to develop legislation concerning animals and other initiatives to bring animal rights and interests to the attention of the public and to work towards realising them, i.e. to develop a society in a way that a respectful coexistence between humans and animals is factually possible. The public authorities have to create such conditions whereby the rights are also protected against single violation. Public authorities must refrain from infringing upon fundamental animal rights.

Subsection 2 determines that the fundamental rights of animals can only be restricted if it is necessary to protect the fundamental rights of people or animals (Principle of Necessity). The principle of necessity also covers the right to life proposed under Section 3 (1) of the fundamental rights of wild animals' respectively and Section 4 (1) of the fundamental rights of animals in need of human care. An animal can only be killed if it is necessary and if there are no other reasonable means to protect humans, animals or a particular species or the environment. The killing of an animal must be carried out in the manner prescribed by law, that does not cause unnecessary suffering to the animal.

When setting restrictions, the essential content of the rights must be respected, and the restrictions must be as limited as possible to the objective pursued (Principle 
of Proportionality). However, exceptional circumstances may justify a broader restriction, as for example in a general emergency, but even in such a case, the restrictions should be kept to a minimum and be removed by law as soon as possible.

Furthermore, the restrictions on the fundamental rights of animals must be regulated by law. The requirement of law-making implies a prohibition on delegating the power to restrict fundamental rights to a lower level than an Act.

\section{3. Fundamental rights of wild animals}

The rights provided in Section 3 of the proposal apply to wild animals. "A wild animal" means an animal that lives independently of humans in a natural habitat. This article also applies to animals that have adapted to life in a human-made environment, e.g. cities, but that are not dependent on human care.

According to subsection 1, wild animals have the right to live in freedom and in their natural habitat. Three rights are guaranteed in this section: the right to life, the right to live in freedom and the right to natural habitat.

In general, it is forbidden to keep wild animals in a domestic setting. However, temporary capture is allowed to provide medical care for an animal or for other acceptable reasons. However, an animal kept for the purpose of providing temporary medical care, or for some other acceptable temporary necessity, must be released into the wild when its condition allows for this, assuming it can re-adjust to life in the wild without any difficulties ${ }^{37}$.

The right to life is closely connected to the other rights protected under this subsection since the right to freedom and the right to natural habitat also protect life. The right to life protects the animal from the deprivation of life both by killing and by causing the destruction of its living possibilities. Obviously, the right to life does not protect the animal from destruction and suffering occurring in nature.

The right to freedom includes the right to engage in the animal's natural behaviour freely, the right to move freely and choose its location in the environment, and the right to bodily integrity. Bodily integrity presumes the right of the animal to be secure against actions that could cause bodily harm. However, this right does not exclude the resettling of an animal to a more suitable environment if the coexistence of humans and animals in the same area is impossible in practice.

The right to live in its natural habitat protects the animal from such interferences with the habitat that will result in a decrease in the animal's chances to survive or will render those chances non-existent. This right takes precedence in situations where measures aimed at changing the environment would if implemented, endanger the conditions for the welfare or life of an animal. Because the habitat requirements of animals can vary greatly, the right to live in their natural habitat must be examined in the context of the needs of the species and of the individual animal. Certain species require particular living conditions, while others will thrive in a variety of habitats.

\footnotetext{
${ }^{37}$ If the animal requires permanent care and this can be arranged without infringing upon its fundamental rights, the animal is considered as belonging to the category of animals listed in Section 4 of the proposal.
} 
The second subsection of Section 3 provides that efforts must be made to help a sick, injured or otherwise incapacitated wild animal. However, if the animal is in such a condition that keeping it alive would clearly be cruel, the animal must be euthanised in compliance with the demands provided in an Act. In assessing apparent cruelty, the animal's overall condition and its prospects for future life must be taken into account in addition to its suffering.

\section{4. Fundamental rights of animals dependent on human care}

The rights provided in Section 4 apply to animals that are dependent on human care. The owner or caretaker of the animal is not absolved of their responsibility towards the animal that is dependent on their care by releasing the animal into the wild, unless the release is a solution justified by its benefit to the animal. Such situations may, for example, occur in conjunction with animals released after medical care, as noted in a previous paragraph in this paper.

According to subsection 1, animals have the right to life and to express natural behaviours and to have their basic needs fulfilled. These rights are closely interlinked with the other rights stipulated by this section. The right to life has two dimensions. Firstly, an animal has the right not to be deprived of its life intentionally or negligently. Secondly, the right to life entails the duty to secure by active measures for the animal the conditions for its life. Such measures include preventive animal protection and health care.

Natural behaviour means the behaviour that the animal is strongly motivated to engage in and that this engagement reduces the motivation for the said behaviour ${ }^{38}$. In other words, the animal's need to behave in a certain way is reduced to the satisfaction of the animal. Natural behaviours vary between different animal species. However, the main behavioural characteristics include, in all cases, movement and physical activity, grooming, exploration and feeding behaviours, playing, care and species-specific rest activities (such as hens need to sleep on a perch). The right to exhibit natural behaviours also entails, depending on the animal species, the right to live alone or with other members of the species.

Care, as a behavioural need, involves both taking care of another and being cared for. It involves the right of an animal to care for its offspring and the right of the offspring to be cared for. The right to natural behaviour also includes the behaviours that are necessary for the animal only in certain situations or stages of life, such as a calf's need to suckle or a sow's need to nest before farrowing. The right to natural behaviour shall be evaluated both from the perspective of the species and of the individual animal.

Fulfilling the animal's basic needs means ensuring the rights stipulated in Section 4 so that the animal may fulfil its needs independently or with the help of a human activity. Human activity means, for example, walking a dog so that the animal can engage in exercise and relieve itself outside. Fulfilling the rights stipulated in this sec-

\footnotetext{
${ }^{38}$ This definition is made by the emeritus professor in veterinary medicine Bo Algers in Sweden (Algers 1990 and 2008).
} 
tion also means measures designed to prevent disordered behaviour and suffering in animals. According to the proposal, those measures shall be specified in an Act.

According to subsection 2, an animal has the right to experience and express positive emotions, as well as the right to be protected from fear, pain, distress and suffering caused by humans. This subsection mainly stipulates the rights relating to animals' range of experiences and stipulates both negative and positive obligations on humans. A person shall refrain from measures that cause suffering or other negative emotions to an animal. At the same time, active attention shall be paid to the fulfilment of the right to natural behaviour stipulated in subsection one by allowing the animal to experience and express positive emotions.

According to subsection 3, an animal has the right to suitable food and drink in sufficient amounts that are necessary for its welfare and for preserving its health. The energy and food requirements of individual animals depend on the species, age, animal premises, air temperature, physical condition of the animal and the energy expenditure of the animal at a given time. A sufficient amount of food also means that the animal can experience satiety. The caretaker of the animal is responsible for meeting its nutritional needs and for the suitability of the food provided to promote the health and welfare of the animal in question. The food shall be provided in a manner that enables the animal to eat in a natural posture. The animal has the right to decide when to eat according to its individual needs. The animal must not be overfed on purpose or due to negligence so that the animal's welfare or health is adversely affected by excess weight. An animal species must also not be bred in such a manner that its need to eat detrimentally affects the animal's wellbeing or health, leading for instance to obesity or constant hunger. If such a breed has already been produced, the breed may not be sustained by producing new members. Animal breeding and the prohibition of breeding are explicitly regulated in Section 5 of the proposal.

Access to water is a fundamental physiological need of an animal. The water provided for the animal must be of good quality, sufficient in quantity and made accessible so that the animal can drink without difficulty. The animal has the right to decide when to drink according to its individual needs. Therefore, water must be always available if it is not justified otherwise for veterinary medicine reasons. Supplying the animal with frozen water is not in compliance with the right to drink provided in this section.

According to subsection 4, an animal has the right to an appropriate living environment, including shelter and a rest area. The living environment must be sufficiently spacious, well lit, clean, safe and also appropriate concerning the needs of the animal and the species. In assessing the appropriateness of the living environment, the other rights guaranteed by Section 4 must be taken into account. For example, when assessing sufficient spaciousness of the living environment, the right to the natural behaviour guaranteed in subsection one must also be taken into account. Furthermore, an animal has the right to shelter, for example, from adverse weather conditions. The temperature of the shelter must be suitable for the animal's welfare. Therefore, in a hot environment, access to shade or a cooler area must be granted. To fulfil the animal's need for rest, there must be a rest area included in the living environment. The 
qualities of the rest area must meet the needs of the animal and therefore be sufficiently large, clean and dry.

According to subsection 5, an animal has the right to receive appropriate medical care without delay. However, an animal has the right to be euthanised if it is in such a condition that keeping it alive is cruel. The rationale of Section 3, subsection 2, stipulates a respective right with regard to wild animals. The responsibility for continuing appropriate treatment on the premises after the veterinary or other medical care is completed to the caretaker. The animal must also be guaranteed peace and a chance to recover after treatment.

To summarise Section 4, the aim is to create the solid legal ground, as comprehensively as possible, for the balancing of different interests in human-animal relations de facto.

\section{5. The prohibition of animal breeding}

The fifth section pertains to animal breeding. In animal breeding, the starting point should always be the best interests of the animal. Hence, breeding must not cause harm to the welfare or health of animals.

Thus, Section 5 requires that only physically and psychologically healthy animals may be used for breeding. It is prohibited to use for breeding animals that will suffer or might suffer physical or psychological harm as a result. An animal may not be inseminated or made to inseminate other animals against its will. This prohibition applies to both male and female animals.

As one can note, this section does not prohibit all breeding of animals. The Finnish Animal Rights Lawyers Society working group discussed the topic profoundly and comprehensively and concluded that, if the breeding is carried out respecting the requirements and rights stipulated in the proposal, it may be helpful for the health and welfare of animals under certain circumstances. Regulating the matter at the constitutional level gives it the gravity needed at the current time. The primary understanding and the goal to strive for is, however, that humans do not breed animals at all for human purposes in the future.

\section{FINAL REMARKS: FUNDAMENTAL ANIMAL RIGHTS AS NORMATIVE RE- SPONSES TO OPPRESSION AND EXPLOITATION}

In 1993, Catharine McKinnon wrote about human rights as a normative paradigm, that “(..) behind all law is someone's story - someone whose blood, if you read closely, leaks through the lines" (MacKinnon 1993:84). Concerning the oppression and exploitation of animals, we do not even have to read between the lines to see the blood leaking out. It is present everywhere in society (and in the state of the Earth).

To be oppressed is to be subjected to the unjust or cruel exercise of power or authority (Winston 2007:287). In human rights law, the oppressed are defined by Morton Winston "as an especially powerless and vulnerable class of persons because they are subject to forces that are beyond their control that deny them the ability to pro- 
tect their most basic interests" (Winston 2007:287). He characterises oppression as consisting of three elements: 1) it relies on an assortment of different practices that together function to create the systematic nature of oppression; 2) the objects of systematic oppression are necessarily unable to rescue themselves from their situation; and 3) objects of systematic oppression are oppressed because of a group identity (Winston 2007:287-288). For instance, women are oppressed qua women; animals are oppressed qua animals.

The definition of the systematic nature of oppression is also well suited to the characterisation of the current systematised oppression and exploitation of animals. This means that: 1 ) the welfare paradigm as the basis for animal protection/welfare legislation makes legal and maintains the systematic exploitation of animals, 2) animals cannot help themselves out of systematic exploitation and oppression by humans, and 3) animals are exploited by humans because they are animals and thereby subordinated (by) humans. In other words, animals are subjected to human power as a given. As such, also current animal protection legislation is both a response and an outcome of that oppression, and at the same time a prerequisite for the continuation of the systematic exploitation, that, for instance, conventional farming ${ }^{39}$ of animals reflects.

An example within the EU of legal oppression and exploitation of animals is the practice of transporting (exporting) live animals within the EU and from the EU to third countries. It is well documented that there are severe welfare problems and severe suffering caused to billions of animals annually during transport ${ }^{40}$ regardless of Council Regulation (EC) No 1/2005 on the protection of animals during transport and the several judgements made by the Court of Justice of the European Union (ECJ) concerning the enforcement of the law, stating that the interpretation of a specific provision should not make the aim of the statute in question meaningless ${ }^{41}$. However, even with stricter animal welfare legislation based on a welfare paradigm and effective enforcement, the negative impact on animals would be significant. Notably, in this case, because animal suffering is inherent, especially in long-distance transport and also because the transport takes the animal to the endpoint of its life (unnecessarily for example of human survival). In general, this is because the anthropocentric basis of the legislation (the welfare paradigm) substantially restricts the lawmaker and the interpreter of the animal protection legislation. As noted already earlier in the paper, the content of Article 13 in the TFEU and animals' weak legal status about

\footnotetext{
${ }^{39}$ Including the transportation and slaughter of animals.

${ }^{40}$ The Parliament of European Union: Animal welfare: Parliament wants better protection for transported animals: http:/www.europarl.europa.eu/news/en/headlines/society/20190206STO25113/animal-transport-parliament-wants-better-protection. Published February 2019. Retrieved April 2019.

${ }^{41}$ Find all the judgements by the ECJ concerning the transportation of animals here: https://eur-lex. europa.eu/search.html?typeOfCourtStatus=COURT JUSTICE\&DB TYPE_COURT=COURT JUSTICE\&text-

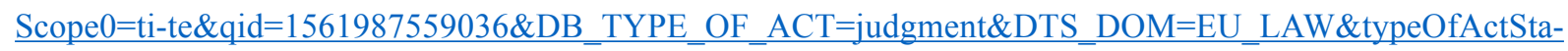

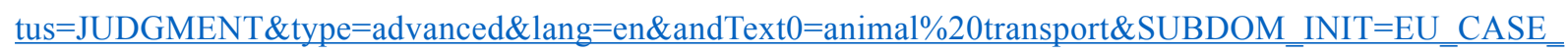
LAW\&DTS SUBDOM=EU CASE LAW and the Animal Angels reports on live transports of animals: https://www.animals-angels.de/en/publications/documentations.html (especially the report on the Myth of Enforcement).
} 
humans makes, the outcome inevitable and maintain the instrumentalised approach towards other sentient beings. Therefore, it is equally undeniable that, changes in legislation that are based on the welfare paradigm cannot lead to significant changes in human-nonhuman coexistence. To bring about that kind of change, fundamental and re-evaluative normative responses are needed to strengthen the legal status of animals in relation to humans and, most importantly, to change human behaviour and attitudes towards animals.

The protection of life itself and the safeguarding of the fundamental interests and rights of sentient beings should not be dependent on the species in question or on the self-righteous supremacy of humans. As the history of human rights shows, legislation on fundamental rights has been the foundation of change, a normative response by society to end oppression and exploitation (Winston 2007:286), and so too will the fundamental rights of animals be in the future.

FUNDING: This research received no external funding.

CONFLICT OF INTEREST: The author declares no conflict of interest.

ACKNOWLEDGEMENTS: I would like to thank Hanna Mamzer for the initiative to this article, the reviewers and editors for their excellent work, my dear colleagues Paula Klami-Wetterstein for all the crucial comments during the writing process and Jane Honka for the language check well needed in the end.

\section{REFERENCES}

Algers, Bo. 1990. “Naturligt beteende - ett naturligt begrepp?” (natural behaviour - a natural concept?). Svensk Veterinärtidning 42(12): 517-519. (only available in Swedish).

Algers, Bo. 2008. Naturligt beteende - lagen och biologin. Djuren är väl också människor - en antologi om hälsa och välbefinnande i djurens och människans värld (natural behaviour - the law and biology). Sveriges lantbruksuniversitet, Institutionen för husdjurens miljö och hälsa, Avdelningen för husdjurshygien. Rapport 20. (only available in Swedish).

Bailey, R. \& Froggatt, A. \& Wellesley, L. 2014. Livestock - Climate Change's Forgotten Sector. London: Chatham House. The Royal Institute of International Affairs.

Francione, Gary L. \& Robert Garner. 2010. The Animal Rights Debate. New York: Columbia University Press.

Gerten, Diter, Johan Rockström, Jens Heinke, Will Steffen, Katherine Richardson, \& Sarah Cornell. 2015. "Response to Comment on 'Planetary boundaries: guiding human development on a changing planet'.” Science 348(6240): 1217. https://doi. org/10.1126/science.aab0031

Isomäki, Risto. 2016. Meat, Milk and Climate. Helsinki: Into.

IUCN Annual Report. 2018: 70 years: International Union for Conservation of Nature.

Koneswaran, Gowri and Danielle Nierenberg. 2008. "Global Farm Animal Production and Global Warming: Impacting and Mitigating Climate Change.” Environmental 
Health Perspectives 116(5): 578-582.

Kurki, Visa. 2017. A Theory of Legal Personality. Doctoral Thesis. Cambridge University. Hessler, Kathy, Joyce Tischler, Pamela Hart \& Sonia S. Waisman. 2017. Animal Law New Perspectives on Teaching Traditional Law. Durham, North Carolina: Carolina Academic Press.

MacKinnon, Catharine. 1993. “Crimes of war, crimes of peace.” Pp. 84 in Human Rights: The Oxford Amnesty Lectures, edited by S. Shute and S. Hurley. New York: Basic Books.

Pietrzykowski, Tomasz. 2018. Personhood Beyond Humanism. Animals, Chimeras, Autonomous Agents and the Law. Cham: Springer Briefs in Law.

Pöyhönen, Juha, ed. 2002. An Introduction to Finnish Law. Helsinki: Kauppakaari Finnish Lawyer's Publishing.

Rojas-Downing, M. Melissa, A. Pouyan Nejadhashemi, Timothy Harrigan \& Sean A. Woznicki. 2017. "Climate change and livestock: Impacts, adaptation, and mitigation.” Climate RiskManagement 16/2017: 145-163.DOI: https://doi.org/10.1016/j. crm.2017.02.001

Scarborough, Peter, Paul N. Appleby, Anja Mizdrak, Adam D. M. Briggs, Ruth C. Travis, Kathryn E. Bradbury, \& Timothy J. Key. 2014. "Dietary greenhouse gas emissions of meat-eaters, fish-eaters, vegetarians and vegans in the UK." Climatic Change 125:179-192. DOI: https://doi.org/10.1007/s10584-014-1169-1

Sowery, Katy. 2018. "Sentient Beings and Tradable Products: The Curious Constitutional Status of Animals under Union Law." Common Market Law Review 55(1): 55-100.

Wahlberg, Birgitta. 2011. Produktions- och slaktdjurs rättsposition med utgångspunkt $i$ EU-lagstiftningen och EU-domstolens tolkningslinjer samt i individens ansvar över miljön (the legal status of farm and slaughter animals based on EU legislation subject to the interpretations made by the European Court of Justice and Section 20 in the Constitution of Finland). JFT 1/2011:34-66 (only available in Swedish). Winston, Morton. 2007. "Human Rights as Moral Rebellion and Social Construction." Journal of Human Rights 6:279-305.

\section{BIOGRAPHICAL NOTE}

Dr.Soc.Sc. (public law) Birgitta Wahlberg works as a university teacher in public law at the Faculty of Social Sciences, Business and Economics, Åbo Akademi University, Finland. She has published the first animal law textbook in Finland and several articles about animal law issues. Wahlberg is founder of the Global Journal of Animal Law. She is also co-founder and chairperson of the Finnish Animal Rights Lawyers Society.

OPEN ACCESS: This article is distributed under the terms of the Creative Commons Attribution Non-commercial License (CC BY-NC 4.0) which permits any non-commercial use, and reproduction in any medium, provided the original author(s) and source are credited. 
